\title{
REVIEW
}

\section{Hepatitis A in workers exposed to sewage: a systematic review}

\author{
C Glas, P Hotz, R Steffen
}

\begin{abstract}
Objectives-To assess whether the scientific literature supports the hypothesis that workers exposed to sewage are at higher risk of hepatitis A (HA).

Methods-All original papers reporting epidemiological studies published in English, French, or German which reported on the risk of HA infection in workers exposed to sewage were eligible. They were identified by several methods and each original paper was assessed independently with a checklist by two people. Studies were classified according to the strength of their design. Non-eligible studies were also examined to assess the impact of publication bias. If the risk estimates diverged widely, causes for heterogeneity were assessed. A distinction was made between seroprevalence studies based on subclinical HA (defined only by the presence of anti-HA antibodies) and clinical HA.

Results-17 eligible studies were identified. No indication of an increased risk of clinical HA could be found. For seroprevalence the studies with the strongest design suggested a slightly increased risk of subclinical HA with an odds ratio (OR) $<2.5$. Heterogeneity was considerable and precluded a meta-analysis. Considering non-eligible studies would still decrease the OR.

Conclusions-The systematic review does not confirm an increased risk of clinical HA in workers exposed to sewage. An increased risk of subclinical HA cannot be excluded but the association between seropositivity and exposure to sewage was not strong and became still weaker if publication bias was taken into account. (Occup Environ Med 2001;58:762-768)
\end{abstract}

Keywords: hepatitis A; sewage; systematic review

ungalversicherungsanstalt des Kantons Zürich (SVA Zürich),

Röngtenstrasse 17, Zürich, Switzerland C A Glas

Correspondence to: Dr P Hotz

photz@ifspm.unizh.ch

Accepted 4 July 2001
The prevalence of hepatitis A (HA) as define by the presence of antibodies against $\mathrm{HA}$ (anti-HAV antibodies) increases with age and is inversely related to socioeconomic level. ${ }^{1-5}$ The disease used to occur mainly in childhood, when it is mostly $(70 \%$ of children $<6$ years of age) asymptomatic. As a result of better
Main messages

- Studies on the incidence of clinical hepatitis A (HA) do not show an increased risk in workers exposed to sewage.

- Seroprevalence studies may show a moderately increased risk of subclinical HA infection.

- Results of seroprevalence studies may be flawed by several methodological factors.

Policy implications

- Systematic HA vaccination of every worker exposed to sewage will have little effect on the incidence of clinical HA.

- Vaccination of the heavily exposed workers may be of value but this has hitherto not been demonstrated.

hygienic conditions, ${ }^{6-8}$ children are nowadays less often infected. The disease is usually symptomatic among older children and adults, with jaundice occurring in more than $70 \%$ of patients. Adults are incapacitated for 4-6 weeks. ${ }^{9}$ Eleven per cent to $22 \%$ of people with HA are admitted to hospital, and the case fatality rate is $1.8 \%$ in those older than $50 .^{5}$

The transmission of the disease occurs by the faecal-oral route. Thus, sewage workers might be at risk of HA through aerosols, ${ }^{10-14}$ smoking, and eating. Younger sewage workers may now be at greater risk of HA than the older ones as they often have not been infected during childhood.

Opinions on the need to vaccinate sewage workers diverge widely. Whereas some authors recommend a systematic vaccination because of the increased risk found in sewage workers ${ }^{18}$ 15-21 others do not consider vaccination necessary. ${ }^{5223}$ Some occupational health specialists just recommend immunisation for "maintaining labor peace", ${ }^{24}$ or to prevent litigation costs, ${ }^{25} 26$ or only after evaluating the specific epidemiological situation. ${ }^{27}$ The reasons for these differences are unclear and because no systematic review analysing the literature could be found, a systematic review was conducted. The purpose was to see whether the scientific literature supports the hypothesis 
(a) Exposure assessment:

At least two exposure surrogates were used-for example, (1) duration of exposure and (2) intensity, frequency, or probability of exposure

Influence of misclassifications assessed or at least discussed

(b) Main outcome measures:

Definition of the type of immunoglobulins determined for assessing seroprevalence

Definition of the term "clinical" hepatitis A

(c) Biases:

Exclusion of vaccinated people ${ }^{\star}$

Distinction between hepatitis A occurring before and after beginning of employment

(d) Confounding factors:

At least consideration of the three following variables: age, travelling in endemic areas, socioeconomic status (defined according to education, income, or another recognised classification system)

If present consideration of locally important confounding factors-for example, consumption of shellfish

(e) Control group:

The selection and the composition of the control group must exclude important flaws capable of introducing a bias

*If no information on vaccination could be found, the period during which the study was conducted —or if not indicated the year of publication - was used as an indicator of the probability of vaccination. A vaccination was considered as very unlikely if the study was performed before 1992 .

that workers exposed to sewage are at higher risk of HA.

\section{Methods}

All original studies that were published in English, French, or German and that assessed the risk of HA in workers exposed to sewage were sought with several methods. A Medline search (Ovid software, 1966-99) was conducted (a) with text words ( $\$=$ truncation symbol): drainag $\$$ and hepatitis; (sew $\$$ or sanita $\$$ ) and hepatitis $\mathrm{A} ;(b)$ with $\mathrm{MeSH}$ terms: sanitation or waste products and hepatitis or hepatitis A; drainage and hepatitis $\mathrm{A} ;(c)$ with hepatitis $\mathrm{A}$ as $\mathrm{MeSH}$ term and sew\$ as text word. All MeSH terms were "exploded" and the literature search was carried out again after completing the review. Secondly, the data base of the Unit of Occupational and Environmental Medicine (based on a manual search in Current Content Life Sciences 1200 and in journals for occupational health; period 1986-99) was used. Thirdly, the bibliography of each article included in the review was checked. Finally, two specialists in the field were asked for further (unpublished) literature. Both peer reviewed and non-peer reviewed journals were included.

Because letters, abstracts, and governmental reports did not usually offer a full account on a survey, this type of reference was not eligible. However, as non-publication in scientific journals may also be due to publication bias, clues to "grey" areas in the literature were searched for. The studies not published in English, French, or German were dealt with in a similar way but the source of information was restricted to the abstract or the figures and tables. To make comparisons between eligible and non-eligible literature easier the second is presented in a separate section of the tables. The impact of non-eligible literature is assessed

Table 2 Definition of the categories used for classifying cross sectional studies

\begin{tabular}{ll}
\hline Category & Definition (according to the criteria listed in table 1$)$ \\
\hline 4 & Criteria $(a-e)$ are all met. \\
3 & Criteria $(a, b$, and $d$ ) are met; criteria ( $c$ or $e$, or both) are only partly met \\
2 & $(a)$ Exposure assessment at least qualitatively - for example, job name only \\
& $(b)$ Criterion $(b)$ is met \\
& $(d)$ Only one or two of the four most important confounding factors considered \\
& $(c$ and $e$ ) These criteria may or may not be met \\
& Still less comprehensive than category 2 \\
\hline
\end{tabular}

in the discussion by comparing strength of design and results with those of published studies.

Each article was independently assessed by two occupational physicians with a checklist considering period and place, study design, eligibility criteria, selection and characteristics of the study population, exposure assessment, definition of outcome, biases, and confounding factors. Divergences were resolved by consensus. In cases of duplicate studies information from all publications was taken into account. No eligible studies were excluded on the basis of this assessment.

Firstly, the studies were classified according to the strength of their design (in order of decreasing strength: cohort, case-control, cross sectional, and case reports or series). Secondly, it was attempted to single out the most convincing studies and to assess an overall risk estimate based on those studies only. The quality criteria defined four categories ranging from 1 (not very convincing) to 4 (very convincing) (table 1 and table 2). Owing to the number of studies in each design stratum this could be done for the cross sectional studies only. If the risk estimates diverged widely, causes for heterogeneity were assessed.

The appraisal of the study characteristics raised some problems regarding vaccination, exposure definition, and risk estimates.

Whether HA vaccine was used at the time of the study is often not known either because it is not stated in the publication or because the study was carried out before the introduction of a vaccine. If no information on vaccination could be found, the period during which the study was conducted-or if not indicated, the year of publication - was used as an indicator of the probability of vaccination. A vaccination was considered as very unlikely if the study had been performed before 1992 .

For this review an exposed worker was defined as a worker exposed to sewage. It was not possible to define the exposure more precisely with respect to minimal duration of employment, exposure intensity, frequency, or type. Indeed, exposure has mostly not been assessed objectively and the tasks of the workers are often described only very briefly. Thus, the use of a standardised terminology was not 
Table 3 Studies with clinical outcome

\begin{tabular}{|c|c|c|}
\hline Reference & Definition of outcome & Results Comments \\
\hline \multicolumn{3}{|l|}{ Eligible studies } \\
\hline Lerman et al (1999) ${ }^{28}$ & Clinical HA in 1993-4 & $\begin{array}{l}\text { HA patients retrieved from three sources: }(1) \text { cases } \\
\text { reported to the local health district offices (HA is a } \\
\text { notifiable disease in Israel); (2) reports from } \\
\text { laboratories (IgM); (3) discharges from general } \\
\text { hospitals. } 85 \% \text { Of the cases were confirmed } \\
\text { serologically. }\end{array}$ \\
\hline Brugha et al $(1998)^{29}$ & Clinical diagnosis of viral hepatitis & $\begin{array}{l}\text { The company records showed no cases of viral } \\
\text { hepatitis in the } 5 \text { years before the study. }\end{array}$ \\
\hline \multirow[t]{2}{*}{ Trout et al $(2000)^{33}$} & History of jaundice or hepatitis in the past & $\begin{array}{l}\text { History of hepatitis more frequent in exposed } \\
(12 \%-13 \%) \text { than in control subjects }(0 \%-1 \%) \text {. }\end{array}$ \\
\hline & Definition of hepatitis: NI & $\begin{array}{l}\text { Difference hardly interpretable because of differences } \\
\text { in age, sex and socioeconomic levels between the four } \\
\text { subgroups. Moreover, no distinction between time } \\
\text { before and after beginning employment was done and } \\
\text { no good association between anti-HAV antibodies and } \\
\text { clinical history was found. }\end{array}$ \\
\hline DeSerres et al $(1995)^{35}$ & History of jaundice and hepatitis & $\begin{array}{l}\text { No case of jaundice after the beginning of } \\
\text { employment was found. }\end{array}$ \\
\hline $\begin{array}{l}\text { Schlosser and Roudot-Thoraval } \\
(1995)^{36}\end{array}$ & History of jaundice & $\begin{array}{l}\text { History of jaundice not more frequent in the exposed } \\
\text { group. } \\
\text { No distinction between jaundice before and after } \\
\text { beginning employment. }\end{array}$ \\
\hline Heng et al $(1994)^{37}$ & $\begin{array}{l}\text { Hospital admission because of acute HA after start of work in } \\
\text { the sewage treatment plant. }\end{array}$ & No control group \\
\hline Skinhoj et al $(1981)^{38}$ & $\begin{array}{l}\text { History of "jaundice or liver disease unrelated to gall bladder } \\
\text { disease" }\end{array}$ & $\begin{array}{l}11 \text { Episodes of jaundice reported. Eight cases occurred } \\
\text { before present occupation (three sewer workers, three } \\
\text { gardeners, two clerks). Three cases in sewer workers } \\
\text { but none in the control groups occurred during their } \\
\text { current employment }\end{array}$ \\
\hline Khuder et al $(1998)^{39}$ & $\begin{array}{l}\text { Occurrence of jaundice or HA 1995-1996. Self administered } \\
\text { questionnaire }\end{array}$ & No case of jaundice or HA recorded in either group \\
\hline Ross et al $(1998)^{44}$ & $\begin{array}{l}\text { Diagnosis of HA reported by consultants in communicable } \\
\text { diseases control }(n=116) \text {. }\end{array}$ & No cases occurred in sewerage workers \\
\hline \multicolumn{3}{|l|}{ Non-eligible studies } \\
\hline Clark et al $(1984)^{45}$ & Continuous collection of self reported illness data & $\begin{array}{l}\text { Both workers who seroconverted reported hepatitis } \\
\text { symptoms at a time consistent with the period in } \\
\text { which the seroconversion occurred (the number of } \\
\text { seronegative workers at the beginning of follow up was } \\
249 \text { ). }\end{array}$ \\
\hline PHLS working group $(1991)^{15}$ & Cases of HA (interview and salivary IgG and $\operatorname{IgM}$ ) & $\begin{array}{l}\text { Sources for identification of HA cases were apparently } \\
\text { (a) notifications made by medical practitioners and } \\
\text { (b) voluntary laboratory reports. } \\
\text { No increased risk in sewage workers was found } \\
\text { according to Maguire }{ }^{60}\end{array}$ \\
\hline Tornberg and Ronne $(1997)^{48}$ & Notified cases of HA & $\begin{array}{l}\text { HA is a mandatory notifiable disease in Denmark } \\
\text { The authors wrote that sewage workers "may be } \\
\text { particularly at risk although the risk is still low". }\end{array}$ \\
\hline
\end{tabular}

$\mathrm{NI}=$ no information was found in the publication.

possible and the terms used by the authors of the respective study had to be used in the tables.

If no risk estimates were reported, crude odds ratios (ORs) and 95\% confidence intervals $(95 \%$ CIs) were calculated with the information available in the paper (program Epi Info; Center for Disease Control; Atlanta, GA, USA).

\section{Results}

The literature search identified 17 eligible studies: one historical prospective ${ }^{28} 15$ cross sectional, ${ }^{29-43}$ and one descriptive. ${ }^{44}$ They were conducted between the end of the 1970s and 2000 in eight countries, primarily European ones (10 studies). Two were carried out before 1992, the year used as an approximate surrogate for the introduction of vaccination. No randomised control trials and no casecontrol studies were identified. The same literature search identified five non-eligible studies: one cohort (research report), ${ }^{45}$ one case-control (no published full account), ${ }^{15}$ two cross sectional, and one descriptive (published in Italian, Greek, and Danish, respectively). ${ }^{46-48}$ They were conducted between 1975 and 1998 in five countries (four in Europe). At least three studies were carried out in part before 1992, the year used as an approximate surrogate for the introduction of vaccination. Despite several attempts one paper ${ }^{49}$ could not be obtained and it is not known whether it would have been eligible.

Table 3 summarises the results related to clinical HA, and the main characteristics of all studies are presented in a detailed table found on the online version of Occupational and Environmental Medicine.

Two main end points have been considered: clinical hepatitis and seropositivity.

CLINICAL HEPATITIS A

The historical prospective, the descriptive, and seven cross sectional studies used clinical HA as the outcome measure (table 3 ). The historical prospective, the descriptive study and the cross sectional studies by DeSerres $e t a l^{35}$ and Brugha et $a l^{29}$ recorded no excess cases of HA. By contrast, three cases of jaundice during current employment were reported by Skinhoj et $a l^{\beta 8}$ in the exposed group but none among the control group. As the available information is very limited no definitive conclusions could be drawn from four studies 333739 (table 3). 


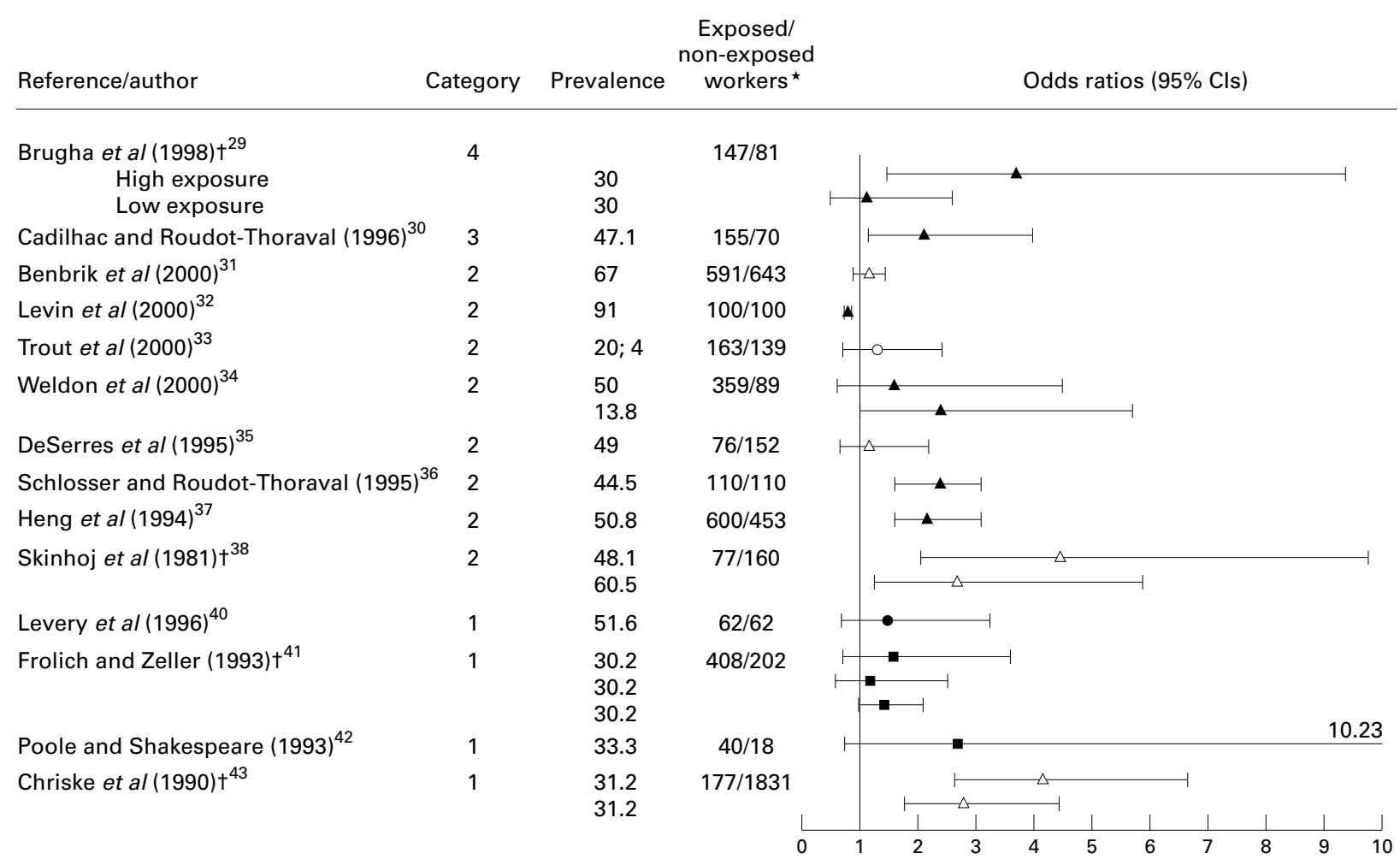

Figure 1 Cross sectional seroprevalence studies: ORs (95\% CIs), and prevalence rates of seropositive subjects in the control groups. Closed triangles =adjusted ORs (95\% CIs), (variables considered for adjustment not identical in all studies); closed squares=crude ORs (only crude ORs were given in the publication); open triangles =crude ORs (95\% CI) calculated with the data available in the publication (no OR given by the authors); open circle $=$ adjusted prevalence ratio $(95 \%$ CI); closed circle $=$ subjects matched on age, sex, and socioeconomic level; prevalence $=$ prevalence rates of seropositive subjects in the control group(s). *Study population entered in the seroprevalence study. HMore than one main OR given in this study.

Excluding those four studies left five studies using three different designs. All these studies but one were negative and the increased risk reported by Skinhoj et $a l^{\beta 8}$ may also be explained by chance (increased risk based on three cases) or bias. Thus, the hypothesis of a more frequent and more severe $\mathrm{HA}$ in unimmunised sewage workers is not supported by these results. The non-eligible studies ${ }^{15} 4548$ are in line with this conclusion (table 3 ).

SEROPREVALENCE STUDIES

All eligible studies having determined seroprevalence were cross sectional. These 14 studies included 3065 exposed workers and 4110 control subjects. Importantly, the size of the control group was largely determined by one single study with 1831 control persons. ${ }^{43}$ Regarding seroprevalence the 20 main comparisons yielded imprecise risk estimates ranging from 0.8 to 4.5 (figure 1 ). Whereas one study reported a significantly decreased $\mathrm{OR}^{32}$ non-significantly increased ORs were found in 10 comparisons, ${ }^{29} 31343540-42$ and definitely increased ORs $(>3)$ were reported three times..$^{29} 38$ In five other comparisons weaker but significant ORs of 2.2 to 2.8 were found..$^{36-3843}$ In one study non-significantly increased prevalence ratios were reported. ${ }^{33} \mathrm{As}$ these large differences in risk estimates suggested some heterogeneity, the influence of study population, confounding factors, exposure characteristics, definition of outcome measure, time period, and study quality was examined.
COMPARABILITY OF THE MAIN FEATURES OF THE CROSS SECTIONAL SEROPREVALENCE STUDIES

Prevalences of anti-HA antibodies ranged from $4 \%$ to $91 \%$ across the control groups of the different studies. It is not possible to know whether the control groups were actually a representative sample of the general population or whether these differences were due to selection bias. Indeed, information on participation rates and representativeness are rather scarce (extra table on the online version of Occupational and Environmental Medicine). In the few studies that included two control groups, an influence of the selection of the control group on the ORs was evident. ${ }^{34} 3842$ However, there was no clear association between seroprevalence in control subjects and ORs across studies. Indeed, OR $>3.5(n=3)$, of 2.2 to $2.4(n=4)$, and $1.2(n=3)$ were associated with prevalences ranging from $30 \%$ to $48 \%, 14 \%$ to $51 \%$, and $30 \%$ to $67 \%$, respectively.

For confounding variables, age and sex may not have been comparable in the control and exposed groups of three studies. ${ }^{41-43}$ Only three studies $^{29} 3033$ out of 14 considered the three essential confounding variables (age, travelling in endemic areas, socioeconomic level) but they used different approaches making direct comparisons difficult. There was no obvious relation between methods used for controlling variables and risk estimates (fig 1).

Similar considerations apply to vaccination and a meaningful analysis after stratifying according to vaccination was not possible 
because the necessary information was too scarce (web table).

That differences in exposure levels impact on the risk estimates is suggested by the findings of Brugha et $a l^{29}$ and to some extent by those of Chriske et $a l^{43}$ but this hypothesis could not be tested. In a few cases $^{29} 30$ a semiquantitative exposure assessment was done by managers or workers. In some other investigations the exposure was characterised by duration of employment. ${ }^{35-38}$ However, the definition differed between studies or was unclear (duration of employment in the present plant only or during the whole working life). Finally, job name as the only exposure surrogate in some reports ${ }^{41-43}$ is probably too simple an indicator. Indeed, exposure sources were very different: work with raw sewage, ${ }^{29}$ workers maintaining the flow of a section of a river polluted with waste water, ${ }^{41}$ subjects working in the system of sewers, laboratory workers, ${ }^{36}$ gully cleaners, cesspit emptiers, etc. ${ }^{42}$ The composition of and the processes used to treat sewage are generally unknown. No objective exposure assessments were made in any cross sectional study. Therefore, it was not possible either to stratify the studies according to exposure or to test a doseresponse relation. Moreover, this issue was further complicated by misclassifications of exposure. Indeed, in some plants the workers carried out several tasks with and without exposure and were moving in and out of high risk jobs. It is currently hardly possible to assess the combined effect of difference in exposure level and misclassifications on the ORs.

Differences in sensitivity and specificity of the test kits or different definitions of a positive test result might explain some divergences. Unfortunately, methodological indications are scarce or even absent in some studies 35364143 and a stratification according to the method of determination of anti-HAV antibodies was impossible.

A decrease of the prevalence of HA infection with time is unlikely to explain the differences of ORs during the past 10 years. The prevalences ranged from $4 \%$ to $91 \%$ and $30 \%$ to $50 \%$ for the periods $1995-9$ and $1990-4$ respectively).

No useful information appeared from the case series and case reports. ${ }^{24}{ }^{64-72}$

\section{FURTHER LITERATURE}

Several studies, the titles of which suggested that they could include useful indications ${ }^{217} 7^{73-81}$ and recommendations of medical boards and books, ${ }^{1}{ }^{15} 21$ 82-87 $^{8}$ were also examined for further literature. Several reviews ${ }^{6816181923262763687188-98}$ were found but the interpretation of the older reviews was made difficult by the lack of a serological diagnostic test or of reliable statistical data. It should be stressed however, that the reviews by Dixon and McCabe, ${ }^{88}$ Safety Committee-California Water Pollution Control Association, ${ }^{71}$ Clark et $a l,{ }^{89}$ and Clark and Linnemann ${ }^{68}$ do not suggest a strongly increased risk of HA in sewage workers.

\section{Discussion}

A major question is whether the selection procedure has excluded studies quite different from those meeting the eligibility criteria and whether there is some indication of publication bias. The exclusion of the two cross sectional seroprevalence studies which found either decreased ${ }^{46}$ or increased risk, ${ }^{47}$ would hardly have modified the results. Indeed, there was no difference pertaining to study design, exposure assessment, outcome measure, and results from the abstracts of these investigations. The same holds true for the descriptive study by Tornberg and Ronne. ${ }^{48}$ By contrast, the exclusion of the cohort ${ }^{45}$ and the case-control study ${ }^{15}$ suggests an important publication bias. Indeed, both studies had a design stronger than the cross sectional one and included large study populations. Moreover, PHLS has conducted investigations of HA outbreaks and an increased risk of occupational exposure to sewage was not found ${ }^{15}$ (the PHLS report summarises extremely briefly both one casecontrol study which should have been negative according to Maguire ${ }^{60}$ and some additional investigations). Consequently, risk estimates calculated only on the basis of investigations published as a full account in scientific journals may represent an overestimation.

Thus, the risk of clinical HA is not increased in workers exposed to sewage, a conclusion supported by both eligible and non-eligible studies. By contrast, the results for subclinical HA, as defined by seropositivity, are somewhat confusing and we were unable to identify a single factor explaining the disparity of the ORs. However, prevalence rate of anti-HA antibodies in the general population, vaccination policy, lack of adjustment for important confounding variables, and differences in levels of exposure to sewage seem to be reasonable explanations. The respective impact of each factor is likely to vary from one study to another and the overall effect is extremely difficult to assess. Altogether, the analysis of the studies, having adjusted at least for age and socioeconomic level, suggests that the exposure effect does not completely disappear after adjusting but that ORs are generally below 2.5 with the possible exception of heavily exposed subgroups. However, these risk estimates should be viewed with caution even if risk estimates of this magnitude may provide evidence of causal association. Indeed, risk estimates below 3 may be due to biases or confounding variables, which occurred fairly often (web table). Moreover, all studies on subclinical HA were cross sectional, a design not capable of controlling for seropositivity before employment. Finally, it is very disturbing that the only study with a stronger design ${ }^{45}$ obviously conflicts with these conclusions.

Dose-response relations were often not examined, non-significant, or difficult to interpret (details can be found on the online version of Occupational and Environmental Medicine). Moreover, misclassifications of exposure have probably confused the relation by either non-differential misclassification or combinations of misclassification and bias. Whereas 
non-differential misclassification reduces $\mathrm{OR}$ towards the null value a combination of bias and misclassification may increase the $O R$ if a high seroprevalence actually due to socioeconomic level, country of origin, or travelling to endemic areas is falsely attributed by erroneous exposure assessments to heavy exposure.

No meta-analysis was done. Indeed, an overall OR could be misleading as meta-analysis cannot correct for biases or lack of consideration of confounding factors. Furthermore, a meta-analysis stratifying according to exposure level would have answered one of the most important questions, that of the dose-response relation, but this was not possible.

These results do not suggest that all sewage workers have to be systematically vaccinated against HA. Indeed, no clue to an increased risk of severe clinical infection was found, and no endemic outbreaks with severe course of HA among sewage workers were reported. As a dose-response relation was found in the best cross sectional study ${ }^{29}$ this finding could be seen as supporting a dose-response relation and, thus, vaccination might be discussed for those workers heavily exposed to sewage. However, this conclusion refers to subclinical HA only and is based on a very limited set of data.

These results suggest that further research should use a cohort design (strength of the design), select the control population very carefully (immunisation and confounders), pay more attention to power (precision of the estimate), and define exposure levels accurately. Further cross sectional studies are unlikely to give new useful information especially because of the limitations of this study design.

To summarise, evidence suggesting an increased risk of HA in sewage workers is based on seroprevalence data from cross sectional studies and not on the incidence of clinical HA. The ORs of about 2 suggested by the most reliable cross sectional studies are in a range compatible with the effect of biases or confounding factors, and publication bias might suggest values higher than those actually occurring. These conclusions are based mainly on investigations from Europe and North America and may not be generalisable to populations of workers with quite different natural immunity.

We thank Professor F Gutzwiller for his support, R Lehmann and $\mathrm{C}$ Scheibling for helping with the literature search, H-P Jauss for performing the figure, and SmithKline Beecham for additional information on risk in sewage workers.

1 Anonymous. Empfehlungen der Standigen Impfkommission des Bundesgesundheitsamtes (STIKO) zur Hepatitis-AProphylaxe. Bundesgesundhbl 1993;36:116.

2 Gasparini R, Pozzi T, Giotti M, et al. Seroepidemiological study on the prevalence of antibodies against the hepatitis A virus in the Province of Siena (Italy) in 1992. F Prev Med Hyg 1993;34:177-82.

3 Studer S, Joller-Jemelka HI, Steffen R, et al. Prevalence of hepatitis A antibodies in Swiss travellers. Eur $\mathcal{F}$ Epidemio 1993;9:50-4.

4 Kunasol P, Cooksley G, Chan VF, et al. Hepatitis A virus: declining seroprevalence in children and adolescents in southeast Asia. Southeast Asian 7 Trop Med Public Health 1998;29:255-62.

5 Centers for Disease Control and Prevention. Prevention of hepatitis A through active or passive immunization. Recommendations of the advisory committee on immuniRecommendations of the advisory committee on immuni-
zation practices (ACIP). MMWR Morb Mortal Wkly Rep zation practices (ACIP)
1999;48(RR-12):1-37.

6 Jost R. Hepatitisimpfung bei Erwachsenen. Schweiz Med Wochenschr 1998;128:1104-9.
7 Koff RS. Hepatitis A. Lancet 1998;351:1643-9.

8 Martet G, Morillon M, Debonne JM, et al. Hepatite virale A: quand une epidemiologie mouvante implique une prophylaxie adaptee. Cahiers Sante 1998;8:113-7.

9 Gutersohn T, Steffen R, Van Damme P, et al. Hepatitis A infection in aircrews: risk of infection and cost-benefit analysis of hepatitis A vaccination. Aviat Space Environ Med 1996;67:153-6.

10 Rylander R, Andersson K, Belin L, et al. Studies on humans exposed to airborne sewage sludge. Schweiz Med Wochenschr 1977;107:182-4

11 Lundholm M, Rylander R. Work related symptoms among sewage workers. Br f Ind Med 1983;40:325-9.

12 Laitinen S, Kangas J, Kotimaa M, et al. Workers' exposure to airborne bacteria and endotoxins at industrial wastewa-

13 Melbostad E, Eduard W, Skogstad A, et al. Exposure to bacterial aerosols and work-related symptoms in sewage workers. Am F Ind Med 1994;25:59-63.

14 Nielsen EM, Breum NO, Nielsen BH, et al. Bioaerosol exposure in waste collection: a comparative study on the significance of collection equipment, type of waste and seasonal variation. Ann Occup Hyg 1997;41:325-44.

15 PHLS working group. The present state of hepatitis A infection in England and Wales. PHLS Microbiology Digest 1991; 8:122-6.

16 Anonymous. Hepatitis A: a vaccine at last. Lancet 1992;339: 1198-9.

17 Tilzey AJ, Palmer SJ, Barrow S, et al. Clinical trial with inactivated hepatitis A vaccine and recommendations for its use. BMF 1992;304:1272-6.

18 Jilg W. Adult use of hepatitis A vaccine in developed countries. Vaccine 1993;11(suppl 1):S6-8

19 Delepine A, Caubet A, Paysant F, et al. La vaccination contre l'hepatite A en milieu professionnel. Arch Mal Prof 1994;55:61-2.

20 Donoghue AM, Hancox B. Hepatitis A vaccination for sewage workers [letter]. N Z Med f 1995;108:235-6.

21 Jost M, Cartier B, Ruegger M, et al. Verhutung blutubertragbarer Infektionen. Luzern: SUVA CNA INSAI, 1997:1-35. 22 Anand JK. Hepatitis A vaccine for sewage workers [letter]. $B M \mathcal{F}$ 1992;305:477.

23 Holzer B. Hepatitis A Impfung. Pharma-Kritik 1992;14:911

24 Warlen AA, Hoff GL. Hepatitis A in waste water treatment plant workers: is vaccination necessary? $\mathrm{f}$ Occup Environ Med 1998;40:515-7.

25 Longson PJ. Hepatitis A vaccine [letter]. BMf 1992;305: 888.

26 Gardner P. Prevention of hepatitis A. Am F Med 1998;105: 452-3.

27 Holzer BR, Egger M. Hepatitis A vaccine. Current Opinion in Infectious Diseases 1995;8:186-90.

28 Lerman Y, Chodik G, Aloni $\mathrm{H}$, et al. Occupations at increased risk of hepatitis A: a 2-year nationwide historical prospective study. Am F Epidemiol 1999;150:312-20.

29 Brugha R, Heptonstall J, Farrington P, et al. Risk of hepatitis A infection in sewage workers. Occup Environ Med 1998; 55:567-9.

30 Cadilhac P, Roudot-Thoraval F. Seroprevalence of hepatitis A virus infection among sewage workers in the Parisian area, France. Eur F Epidemiol 1996;12:237-40.

31 Benbrik E, Tiberguent A, Domont A. Enquete comparative de sero-prevalence de l'hepatite A entre des personnels d'une station d'epuration, de l'assainissement et administratifs. Arch Mal Prof 2000;61:7-28.

32 Levin M, Froom P, Trajber I, et al. Risk of hepatitis A virus infection among sewage workers in Israel. Arch Environ Health 2000;55:7-10.

33 Trout D, Mueller C, Venczel L, et al. Evaluation of occupational transmission of hepatitis A virus among wastewater tional transmission of hepatitis A virus among
workers. $\mathcal{F}$ Occup Environ Med 2000;42:83-7.

34 Weldon M, VanEgdom MJ, Hendricks KA, et al. Prevalence of antibody to hepatitis A virus in drinking water workers and wastewater workers in Texas from 1996 to 1997. F Occup Environ Med 2000;42:821-6.

35 DeSerres G, Levesque B, Higgins R, et al. Need for vaccination of sewer workers against leptospirosis and hepatitis A. Occup Environ Med 1995;52:505-7.

36 Schlosser O, Roudot-Thoraval F. Exposition professionnelle aux eaux usees et risque d'hepatite virale A. Arch Mal Prof 1995;56:23-7.

37 Heng BH, Goh KT, Doraisingham S, et al. Prevalence of hepatitis A virus infection among sewage workers in Singapore. Epidemiol Infect 1994;113:121-8.

38 Skinhoj P, Hollinger FB, Hovind-Hougen K, et al. Infectious liver diseases in three groups of Copenhagen workers: correlation of hepatitis A infection to sewage exposure. Arch Environ Health 1981;36:139-43.

39 Khuder SA, Arthur T, Bisesi MS, et al. Prevalence of infectious diseases and associated symptoms in wastewater treatment workers. Am F Ind Med 1998;33:571-7.

40 Levery G, Besnard C, Dubois F, et al. Hepatite A et exposition professionnelle aux eaux usees. Etude de seroprevalence. Documents pour le Medecin du Travail 1996;65:9-11.

41 Frolich J, Zeller I. Hepatitis-A-Infektionsrisiko bei den Mitarbeitern einer grossen Kläranlagenbetreibergenossenschaft. Arbeitsmed Sozialmed Umweltmed 1993;28:503-6.

42 Poole CJM, Shakespeare AT. Should sewage workers and carers for people with learning disabilities be vaccinated for hepatitis A? BMF 1993;306:1102.

43 Chriske HW, Abdo R, Richrath R, et al. Hepatitis-AInfektionsgefahrdung bei Kanal- und Klarwerksarbeitern. Arbeitsmed Sozialmed Praventivmed 1990;25:285-7. 
44 Ross DJ, Cherry NM, McDonald JC. Occupationally acquired infectious disease in the United Kingdom:

45 Clark CS, Bjornson HS, Linnemann CC Jr, et al. Evaluation of health risks associated with wastewater treatment and sludge composting. Cincinnati, Ohio: US Environmental Protection Agency, 1984:1-245. (EPA-600/1-84-014, Natl Technol Info Serv PB 85-115889.)

46 Salano R, Copello F. An epidemiological study of a group of workers employed in the maintenance of a sewer network and of urban waste water treatment plants (Italian). Med Lav 1998;89:393-403.

47 Arvanitidou M, Constantinidis TC, Doutsos J. Prevalence of hepatitis A virus infection among the employees of a sewage organization. Acta Microbiologica Hellenica 1998;43. 38-43.

48 Tornberg E, Ronne T. Occurrence of hepatitis A infection in Denmark. Ugeskr Laeger 1997;159:2856-61.

49 Levin M, Froom P, Trajber I, et al. Health assessment in sewage workers. Isr f Occup Health 1997;2:205-10

50 Cadilhac P, Roudot-Thoraval F. Evaluation du risque de contamination, par le virus de l'hepatite A, du personnel travaillant en egouts. Enquete transversale. Bulletin Epidemiologique Hebdomadaire 1994;31:139-42.

51 Cadilhac P, Roudot-Thoraval F. Evaluation de la seroprevalence du virus de l'hepatite $\mathrm{A}$, chez und population d'egoutiers de la region parisienne. Arch Mal Prof 1997;58: 374-7.

52 DeSerres G. Need for vaccination of sewer workers against leptospirosis and hepatitis A [letter]. Occup Environ Med 1996;53:71

53 Schlosser O, Roudot-Thoraval F. Exposition professionnelle aux eaux usees et risque d'hepatite virale A. Bulletin Epidemiologique Hebdomadaire 1994;12:54-5.

54 Schlosser O, Roudot-Thoraval F. Exposition professionnelle aux eaux usees et risque d'hepatite virale A. Arch Mal Prof 1994;55:647-8.

55 Roudot-Thoraval F, Schlosser O. Hepatitis $A$ and occupational risk for workers exposed to sewage [abstract]. Madrid: tional risk for workers exposed to sewage [abstract]. Madrid: 3-5 February 1994:51.

56 Schlosser O, Roudot-Thoraval F. Hepatite virale A et expo[letter]. Gastroenterol Clin Biol 1995;19:844-5.

57 Goh KT, Chan L, Ding JL, et al. An epidemic of cockles-associated hepatitis A in Singapore. Bull World Health Organ 1984;62:893-7.

58 Goh KT, Doraisingham S, Monteiro EH, et al. Acute hepatitis A in Singapore: importance of shellfish ingestion in a non-epidemic period. Ann Acad Med Singapore 1987;16: 591-4.

59 Levery G, Thevenas C, Caces E, et al. Hepatite A et risque professionnel [abstract]. Gastroenterol Clin Biol 1995;19:89.

60 Maguire H. Hepatitis A virus infection. Risk to sewage workers unproved [letter]. BMF 1993;307:561.

61 Poole CJM, Calvert IA. Hepatitis A virus infection [letter]. BMF 1993;307:561.

62 Shakespeare AT, Poole CJM. Sewage workers and hepatitis A. Occup Health (Lond) 1993;45:364-6.

63 Hofmann F, Wehrle G, Berthold $\mathrm{H}$, et al. Hepatitis A as an occupational hazard. Vaccine 1992;10(suppl 1):S82-4.

64 DeSerres G, Laliberte D. Hepatitis A among workers from a waste water treatment plant during a small community outbreak. Occup Environ Med 1997;54:60-2.

65 Rimbaut L, Jouffe E, Verger C, et al. Evaluation du cout d'une strategie vaccinale contre l'hepatite A dans une population exposee aux eaux usees. Arch Mal Prof 1996;57: $627-8$.

66 Ohlendorf R. Hepatitis A Infektionsrisiko bei Kanalunterhaltungs- und Kläranlagenarbeitern. Arbeitsmed Sozialmed Umweltmed 1993;28:305-7.

67 Baumgartner E, Dierich M, Hackl M, et al. Kontaminationsrisiko bei Arbeiten in Klaranlagen. Arbeitsmed Sozialmed Praventivmed 1987;9:233-5.

68 Clark CS, Linnemann CC Jr. The use of serum antibody as a means to determine infections from exposure to a means to determine infections from exposure to Control 1986;16:305-26.

69 Corrao G, Zotti C, Sciacovelli A, et al. Infezioni da virus delle epatiti A e B negli addetti alla raccolta rifiuti di Asti. Med Lav 1985;7:145-7.

70 Viraraghavan T. Occupationally related health hazards in wastewater treatment systems. Water Pollution Contro Federation Highlights 1973; (suppl Deeds and data):2-3.
71 Safety Committee of the California Water Pollution Control Association. Report on hepatitis. 7 Water Pollut Control Fed 1965;37:1629-34.

72 Anders W. Die Berliner Kanalbetriebsarbeiter. Zeitschr $f$ Hygiene 1954;139:341-71.

73 Browning GE, Gannon JJ. Operator protection in wastewater treatment plants. F Water Pollut Control Fed 1963;35: $186-90$.

74 Batik O, Craun GF, Tuthill RW, et al. An epidemiologic study of the relationship between hepatitis A and water supply characteristics and treatment. Am 7 Public Health 1980;70:167-8.

75 Iftimovici R, Iacobescu V, Copelovici Y, et al. Prevalence of antiviral antibodies in workers handling wastewater and sludge. Rev Roum Med -Virol 1980;31:187-9.

76 Timothy EM, Mepham P. Outbreak of infective hepatitis amongst sewage sludge spr

77 Scarlett-Kranz JM, Babish JC, Strickland D, et al. Health among municipal sewage and water treatment workers. Toxicol Ind Health 1987;3:311-9.

78 Nethercott JR, Holness DL. Health status of a group of sewage treatment workers in Toronto, Canada. Am Ind Hyg Assoc F 1988;49:346-50.

79 Ortea Tugnoli B, Viejo de la Guerra G, Suarez Echevarria T, et al. Markers of hepatitis A and B virus infection in workers of a municipal sanitary enterprise [letter]. Med Clin (Barc) 1998;110:677

80 Rylander R. Health effects among workers in sewage treatment plants. Occup Environ Med 1999;56:354-7.

81 Rumler R, Papenfuss F. Pravalenz der Hepatitis A bei Kanal- und Rohrleitungsbauern. Arbeitsmed Sozialmed Umweltmed 2000;35:252-8.

82 Benbrik E, Domont A. Aspects jurisprudentiels et regle1998. Arch Mal Prof 1999;60:1-12.

83 Valentin H, Lehnert G, Petry H, et al. Arbeitsmedizin Band 2: Berufskrankheiten. Stuttgart New York: Thieme, 1985:1412

84 Hofmann F, Jilg W, Sanger R, et al. Hepatitis A in der Arbeitswelt. Landsberg/Lech: Ecomed, 1992:1-88

85 Brubacher JR. Sewer and sanitation personnel. In: Greenberg MI, Hamilton RJ, Phillips SD. eds. Occupational, industrial, and environmental toxicology. St Louis: MosbyYear Book, 1997:265-74.

86 Seidel HJ, Bittighofer PM. Arbeits-und Betriebsmedizin. Stuttgart: Georg Thieme Verlag, 1997:1-116.

87 Baxter PJ, Adams PH, Aw T-C, et al. Hunter's diseases of occupations. London: Edward Arnold, 2000:1-1001.

88 Dixon FR, McCabe LJ. Health aspects of wastewater treatment. Fournal of the Water Pollution Control Federation 1964; 36:984-9.

89 Clark CS, Cleary CJ, Schiff GM, et al. Disease risks of occupational exposure to sewage. F Environ Eng Div 1976;102: 375-88.

90 McCunney RJ. Health effects of work at waste water treatment plants: a review of the literature with guidelines for medical surveillance. Am f Ind Med 1986;9:271-9.

91 Altmeyer N, Abadia G, Schmitt S, et al. Risques microbiologiques et travail dans les stations d'epuration des eaux usees. Documents pour le Medecin du Travail 1990;44:373-

92 Fleming LE. Unusual occupational gastrointestinal and hepatic disorders. State Art Rev Occup Med 1992;7:433-48.

93 Margolis HS, Shapiro CN. Who should receive hepatitis A vaccine? Considerations for the development of an vaccine? Considerations for the development of
immunization strategy. Vaccine 1992;10(suppl 1):S85-7.

94 Kindzierski WB, Gabos S. Health effects associated with wastewater treatment, disposal, and reuse. Water Environment Research 1995;67:749-55.

95 Snashall D. ABC of work related disorders: occupational infections. BMF 1996;313:551-4.

96 Abadia G, Squinazi F. Risques infectieux analyses par secteurs professionnels. Secteur de l'assainissement. Arch Mal Prof 1997;58:319-22.

97 De Luca A, Weissenbach T. Impfungen für Erwachsene. Pharma-Kritik 1997;19:77-80.

98 Das A. An economic analysis of different strategies of immunization against hepatitis A virus in developed countries. Hepatology 1999;29:548-52. 